УДК 37.014:005.6

DOI: 10.37026/2520-6427-2021-108-4-16-19
Любомира ІЛІЙчУК,

кандидат педагогічних наук, дочент,

доиент кафедри педагогіки початкової освіти

Прикарпатського національного університету імені Василя Стефаника,

м. Івано-Франківськ, Україна

ORCID: 0000-0003-4274-6903

e-mail: liubomyra.iliichuk@pnu.edu.ua

\title{
МОНІТОРИНГ ЯКОСТІ ОСВІТИ: КОНЦЕПТУАЛЬНІ ПІДХОДИ ТА ПРОБЛЕМИ КЛАСИФІКАЦІЇ
}

\begin{abstract}
Анотація. У статті акцентовано увагу на тому, щуо найважливішим завданням державної освітньоі політики України є забезпечення якості освіти, а ключовим національним пріоритетом і необхідною умовою забезпечення конкурентоспроможності краӥни, ї̈ інтеграиії у європейський освітній простір - розвиток системи моніторингу якості освіти. Схарактеризовано різні підходи до трактування сутності поняття «моніторинг», обгрунтовано дочільність його використання для оиінювання якості освітньої системи. Зазначено, щзо основою розвитку моніторингових досліджень $\epsilon$ кониептуальна складова, що окреслює сутність категорії якості освіти, моделі, види, приниипи і функиії моніторингу. Цей компонент створює передумови
\end{abstract}

для визначення критеріїв та показників якості освіти, технологій $і$ методик збору й опрацювання інформації для підвищення якості в українських закладах освіти, порівняння досягнутих результатів із відповідними міжнародними практиками. Зауважено, щио на сьогодні не існує єдиної загальноприйнятої класифікаиії видів, приниипів і функиій моніторингу якості освіти. Представлені класифікаиії демонструють неабиякі можливості застосування моніторингових досліджень, підтверджують їхню значущість і необхідність використання з метою забезпечення якості освіти в Україні.

Ключові слова: моніторинг, якість освіти, моніторинг якості освіти, класифікація, види моніторингу, принциипи моніторингу, функції моніторингу.

\section{Liubomyra ILIICHUK,}

Candidate of Pedagogical Sciences, Associate Professor, Associate Professor of the Primary Education

Pedagogy Department,

Vasyl Stefanyk Precarpathian National University,

Ivano-Frankivsk, Ukraine

ORCID: 0000-0003-4274-6903

e-mail: liubomyra.iliichuk@pnu.edu.ua

\section{EDUCATION QUALITY MONITORING: CONCEPTUAL APPROACHES AND CLASSIFICATION OF PROBLEMS}

\begin{abstract}
The article emphasizes that ensuring the education quality is one of the most important tasks of the state educational policy of Ukraine. Development of education quality monitoring is a key national priority and a necessary condition for ensuring the country's competitiveness and integration into the European educational space.

The author describes different approaches to the interpretation of the essence of the concept of «monitoring», substantiates the feasibility of its use to assess the quality of education at different levels of functioning. It focuses on the fact that education quality monitoring is considered as a system of information support, a management tool and a set of procedures aimed at monitoring and measuring information on the quality of the educational system.

It is noted that today there is no single conceptual approach to building a system for education quality
\end{abstract}

monitoring in our country, the introduction of new technological solutions to its implementation in educational practice. It is stated that the fundamental basis for the development of monitoring research is the conceptual component, the content of which is to clarify the essence of the category of education quality, substantiation of various models, types, principles and functions of monitoring. This component creates the preconditions for determining the criteria and indicators of education quality and its individual components, methods and techniques of collecting and processing information to improve the quality of Ukrainian educational institutions, comparing achievements with relevant international practices.

The author analyses the scientific literature, which showed that today there is no single generally accepted classification of types, principles and functions of education quality monitoring. The analysed classifications 
demonstrate the wide possibilities of using monitoring research in terms of scale, purpose and technological solutions, which confirms the high importance and necessity of their use to ensure the education quality in Ukraine.

Key words: monitoring, quality of education, monitoring of education quality, classification, types of monitoring, principles of monitoring, functions of monitoring.

Постановка проблеми. Забезпечення якості освіти $є$ одним із найважливіших завдань державної освітньої політики, ключовим національним пріоритетом і передумовою національної безпеки держави. Ще наприкінці ХХ століття світове співтовариство визнало, що освіта, добробут і здоров'я людини є основними чинниками якості життя, а якість освіти - головною метою розвитку громадянського суспільства. Серед характеристик так званого індексу розвитку людського потенціалу, за яким $\mathrm{OOH}$ здійснює порівняння рівнів соціального та економічного розвитку різних країн світу, показник освітньої діяльності є одним із трьох основних індикаторів в інтегрованій оцінці людського розвитку (Організаційно-методичне забезпечення моніторингових досліджень якості загальної середньої освіти, 2011, с. 5). Означені положення визначають ключові напрями впровадження освітніх реформ, забезпечення якості освіти й організації моніторингових досліджень.

Якість освіти вважається основним критерієм ефективності функціонування системи освіти, а моніторинг - необхідним інструментом управління іiі якістю. У зв'язку з цим нині актуалізуються питання створення національних систем моніторингу якості освіти, проведення міжнародних порівняльних досліджень, здійснення зовнішньої незалежної моніторингової оцінки систем освіти міжнародними організаціями й інституціями (Теоретико-методичні засади побудови моніторингових систем оцінювання якості загальної середньої освіти, 2018, с. 12). Безперечно, що розвиток національної системи оцінювання якості освіти $є$ необхідною умовою забезпечення конкурентоспроможності країни й контролю за якістю надання освітніх послуг в закладах освіти. Це вимагає єдиного концептуального підходу до побудови моніторингових систем оцінювання якості освіти в Україні, їхнього порівняння із відповідними міжнародними дослідженнями.

Аналіз наукових досліджень і публікацій. Феномен моніторингу якості освіти $є$ предметом численних зарубіжних і вітчизняних наукових досліджень другої половини XX - початку XXI ст. Так, теоретичні й методичні аспекти моніторингу в освіті розкривають у своїх працях зарубіжні науковці К. Андерсен, Б. Блум, Т. Гусен, В. Кальней, Д. Ківз, Д. Коулман, О. Майоров, Т. Послтвейт, О. Субетто, Р. Тайлор, Р. Торндайк, О. Хрисман, С. Шишов та ін. Біля витоків моніторингу якості освіти в Україні стоять І. Булах, В. Кремень, I. Лікарчук, О. Локшина, Т. Лукіна, О. Ляшенко та ін. Дослідженнями різних аспектів моніторингу в освіті займаються С. Бабінець, Н. Байдацька, С. Боровська, І. Гавриленко, О. Гирба, І. Гириловська, В. Горб, М. Грабар, В. Грабовський, А. Гривко, Г. Сльникова, Ю. Жук, В. Зінченко, С. Кретович, С. Науменко, В. Панасюк,
В. Приходько, Н. Пасічник, 3. Рябова, І. Шимків та ін. Цей доробок дає науково-теоретичне підгрунтя для осмислення досліджуваної проблеми, її подальше вивчення та впровадження прогресивних ідей із метою розвитку ефективної системи моніторингу якості освіти в Україні.

Метою статті $\epsilon$ теоретичне обгрунтування концептуальних підходів до моніторингу якості освіти, аналіз різних видів моніторингових досліджень, принципів і функцій їхнього впровадження в освітню практику.

Виклад основного матеріалу дослідження. Одним із актуальних питань сьогодення є забезпечення якості освіти, про що йдеться у Законах України «Про освіту» та «Про вищу освіту», Національній стратегії розвитку освіти в Україні на період до 2021 року, Національній доктрині розвитку освіти України у XXI столітті та інших нормативних документах. Розглядаючи якість освіти «...необхідною умовою забезпечення сталого демократичного розвитку суспільства» (Національна стратегія розвитку освіти в Україні на період до 2021 року: вебсайт), державні органи управління освітою визначають оцінювання якості освіти та проведення моніторингових досліджень першочерговими завданнями розбудови освітньої системи в Україні.

Якісний рівень освіти забезпечується за допомогою моніторингу, під яким розуміється спеціальна система збору, обробки, зберігання і поширення інформації про стан освіти, прогнозування на підставі об'єктивних даних динаміки й основних тенденцій іiі розвитку та розроблення науково-обгрунтованих рекомендацій 3 метою прийняття управлінських рішень стосовно підвищення ефективності функціонування освітньої галузі (Енциклопедія освіти, 2008, с. 519). Ключову роль у моніторингу відіграє підвищення ефективності системи управління якістю освіти, а систематичність збору інформації є важливим інструментом швидкого реагування на зміни внутрішнього і зовнішнього освітнього середовища (Завгородня, 2020, с. 165).

У науковій літературі окреслено декілька концептуальних підходів до розуміння сутності моніторингу якості освіти. Так, представники інформаційно-статичного підходу (О. Авраменко, С. Донецька, В. Кальней, 3. Капелюк, Н. Пасічник, О. Рєзіна, С. Шишов та ін.) розглядають моніторинг як самоціль, зміст якого полягає у зборі й узагальненні інформації про відповідність досліджуваного об'єкта спеціально розробленим нормам, стандартам і критеріям якості освіти. Відповідно до прогностично-продуктивного підходу (М. Барна, О. Гірний, П. Голубков, Н. Денисова, Г. Сльникова, О. Коваленко I. Маноха, Л. Нікітіна, В. Попов, А. Субетто та ін.) моніторинг визначається як відстеження результативності та спостереження за функціонуванням різних складових освітнього процесу, прогнозування динаміки й основних тенденцій розвитку, вироблення на цій підставі відповідних рішень і рекомендацій (Моніторинг якості освіти: світові досягнення та українські перспективи, 2004; Ішутіна, 2018, с. 57).

Якість освіти визначається сукупністю суспільно визначених вимог, норм і стандартів, яких потрібно досягти системі освіти на певному етапі їі розвитку. Вона $\epsilon$ інтегральною характеристикою, що визначає рівень 
відповідності досягнутих результатів функціонування освітньої системи та окремих її складових суспільним вимогам і особистісним очікуванням. Із цього погляду моніторинг якості освіти розглядається як система, діяльність (процес) та інструмент. Зокрема, моніторинг як системна процедура має на меті з'ясувати чинники розвитку певного суб'єкта освітньої діяльності, зміни стану освіти задля вибору стратегії розвитку та пошуку способів її реалізації; моніторинг як дослідницький процес передбачає виявлення стану функціонування освітньої системи, вивчення процесів, що характеризують їі як функціонуючий організм, якому властивий сталий розвиток; моніторинг як інструментальний засіб оцінювання дає змогу сформулювати висновки й судження про кількісні та якісні показники розвитку досліджуваного об’єкта (Ляшенко, 2007, с. 35).

Моніторинг якості освіти є одним із видів дослідження освітніх проблем і результатів утілення освітньої політики. Він здійснюється на основі певних організаційно-методичних засад, які умовно можна розділити на: концептуальні (визначення концептуальних положень, принципів, функцій, моделей, видів і рівнів моніторингу); нормативно-правові (визначення об'єктів і суб'єктів моніторингу, порядку організації та проведення моніторингових досліджень); технологічні (розробка технології проведення моніторингу, визначення алгоритму, показників і критеріїв оцінювання, прогнозування результатів); методичні (розробка методик створення тестів і обчислення комплексних показників якості освіти на різних рівнях управління системою освіти, науково-методичний супровід проведення моніторингових досліджень) (Теоретико-методичні засади побудови моніторингових систем оцінювання якості загальної середньої освіти, 2018, с. 18-19).

Фундаментальною основою побудови моніторингових досліджень є концептуальна складова, яка містить ключові положення про мету освіти, сутність якості освіти, роль моніторингу в забезпеченні якості освіти, моделі й види моніторингових досліджень, принципи і функції їхньої організації та рівні функціонування. Означений компонент визначає передумови для розроблення критеріїв і показників оцінювання досягнутих результатів системи освіти та окремих їі складових, технологій і методик збору й інтерпретації отриманих даних, прогнозування основних тенденцій розвитку освітньої системи.

На сьогодні не існує єдиної загальноприйнятої класифікації видів та рівнів моніторингу, що використовуються у сфері освіти. Це питання активно досліджують А. Денисенко, Г. Сльникова, В. Кальней, Т. Лукіна, О. Ляшенко, О. Майоров, О. Мітіна, С. Шишов та ін. Наприклад, здійснивши грунтовний аналіз сутності моніторингу в різних сферах життєдіяльності людини, О. Майоров пропонує таку класифікацію видів моніторингу: за засобами, що використовуються для проведення моніторингу - педагогічний, психологічний, соціологічний, економічний, демографічний, медичний; за засобами вимірювання - 3 фізичними й інструментальними вимірюваннями, з опосередкованими вимірюваннями, без спеціальних вимірювань; за цільовими установками - базовий і проблемний; за основами для порівняння - інформаційний, динамічний, порівняльний і комплексний; за ієрархією систем управління - локальний, районний, обласний (регіональний), державний (Майоров, 2005).

Розглядаючи моніторинг як дієвий засіб управління якістю освіти, специфічність якого визначається рівнем управління освітніми системами та цілями проведення моніторингових досліджень, О. Ляшенко окреслює такі види моніторингу: за головною метою - інноваційний та констатуючий; за завданнями - системний, проблемний та аспектний; за часовою ознакою - довготривалий, середньотривалий та короткотривалий; за ієрархічними зв'язками освітньої системи - індивідуальний, локальний (інституціональний), муніципальний (субрегіональний), регіональний, державний (Організаційно-методичне забезпечення моніторингових досліджень якості загальної середньої освіти, 2011, с. 22-24).

Виділяючи декілька підходів до трактування моніторингу у сфері освіти, зокрема як системи інформаційного забезпечення, інструмента управління та сукупності процедур і дій, спрямованих на вимірювання якості освітньої системи, Т. Лукіна визначає такі види моніторингу: за призначенням - інформаційний та управлінський; за засобами, що використовуються для проведення моніторингу: педагогічний (дидактичний, виховний і освітній), соціологічний, психологічний, медичний, економічний, демографічний; відносно об'єкта оцінювання - зовнішній і внутрішній; за ієрархією освітніх систем - інституційний, районний (муніципальний), обласний (регіональний), національний (загальнодержавний), міжнародний (Моніторинг якості освіти: світові досягнення та українські перспективи, 2004, с. 40-47; Лукіна, 2006).

Важливою концептуальною складовою моніторингу якості освіти є система принципів і функцій його застосування в освітній системі. Ця проблема була предметом наукових розробок багатьох дослідників, серед яких Н. Байдацька, О. Гирба, І. Гириловська, В. Горб, Н. Єфремова, В. Зінченко, О. Касьянова, Г. Красильникова, Н. Круглова, Т. Лукіна, О. Ляшенко, О. Мітіна, I. Найдьонова, О. Островерх, В. Приходько, I. Скопилатов, М. Чандра, Л. Щоголєва та ін. Здійснений аналіз наукової літератури засвідчив відсутність загальновизнаної системи принципів моніторингу якості освіти, зокрема дослідники виділяють такі принципи: об'єктивності, узгодженості, безперервності, своєчасності, комплексності, перспективності, гуманістичної спрямованості, рефлективності, відкритості й оперативності (Т. Лукіна); діагностико-прогностичної спрямованості, особистісної доцільності, педагогічної комунікативності, інформаційної інтегрованості, науковості, соціально-нормативної зумовленості, безперервності, цілісності та наступності (В. Горб); науковості, безперервності, наочності, об'єктивності, прогностичності, систематичності, планомірності, свідомості та активності, гласності (Н. Байдацька); науковості, безперервності, діагностико-прогностичної спрямованості, виховної доцільності (О. Мітіна); науковості, безперервності, об'єктивності, валідності, діагностико-прогностичної спрямованості, систематичності, єдності управління і самоуправління (В. Зінченко); безперервності, циклічності, динамічності (I. Найдьонова); мобільності, інтегрованості, конкретності, реалістичності, етичності (В. Приходько); безперервності, цілеспрямованості, цілісності та різнобічності, 
узгодженості, адресності та гласності (О. Гирба); об'єктивності, науковості, прогностичної спрямованості, систематичності, цілісності, повноти (Н. Єфремова).

Не менш важливим компонентом у формулюванні концептуальних положень моніторингу якості освіти $є$ функції, практична реалізація яких здійснюється лише за умови функціонування на основі певних принципів. Функції моніторингу якості освіти визначаються метою конкретного дослідження і замовником його проведення. Саме тому в науковій літературі визначено різні функції моніторингу, серед яких: активізуюча, інформаційна, формуюча, кваліметрична, корекційна, діагностична, аналітична, прогностична, моделююча, управлінського впливу (Т. Лукіна); пояснювальна, аналітична, інформаційна, інтегральна, прогностична, контрольно-оцінна, наказова, формувальна, зворотного зв'язку й удосконалення (I. Скопилатов); аналітико-інформативна, прогностична, діагностична, корекційна (Н. Байдацька); інформативна, порівняльна, рефлексивна, діагностична, інтегративна (М. Чандра); інформативно-аналітична, контрольно-оцінна, діагностична, коригувальна, прогностична (В. Зінченко); інформаційна, діагностична, системоутворювальна, коригувальна, прогностична (О. Касьянова); аналітична, діагностична, інформаційна, прогностична, мотиваційно-стимулююча, управлінська, самоактуалізуюча (І. Гириловська).

Висновки. Моніторинг є сучасним механізмом управління якістю освіти, який дає змогу відстежувати і своєчасно коригувати будь-які процеси, що відбуваються в освітній системі. Аналіз результатів наукових досліджень з означеної проблеми свідчить про неабияке розмаїття поглядів на сутність моніторингу в освіті, виділення класифікаційних ознак різних видів, принципів і функцій моніторингових досліджень. Ці категорії складають концептуальну основу для розроблення алгоритму, чітких критеріїв і показників якості освіти, діагностичних методик та технологій функціонування моніторингових систем і проведення відповідних досліджень.

Перспективи подальших досліджень передбачають розгляд питань, які стосуються імплементації міжнародного досвіту моніторингу якості освіти у вітчизняну освітню практику, визначення шляхів та вдосконалення механізмів внутрішньої системи забезпечення якості в закладах освіти, розроблення чітких критеріїв і показників моніторингу якості освіти на всіх рівнях функціонування і розвитку системи освіти.

\section{СПИСОК ВИКОРИСТАНОЇ ЛІТЕРАТУРИ}

Організаційно-методичне забезпечення моніторингових досліджень якості загальної середньої освіти: монографія. (2011) / за ред. О. І. Ляшенко. Київ: Педагогічна думка. 160 с.

Теоретико-методичні засади побудови моніторингових систем оцінювання якості загальної середньої освіти: монографія. (2018) / за ред. О. І. Ляшенка, Ю. О. Жука. Київ: ТОВ «КОНВІ ПРІНТ». 192 с.

Національна стратегія розвитку освіти в Україні на період до 2021 року: Указ Президента України від 25.06.2013 p. № 344/2013. URL: https://zakon.rada.gov.ua/ laws/show/344/2013\#Tехt (дата звернення: 31.08.2021).

Енциклопедія освіти. (2008) / Акад. пед. наук України; гол. ред. В. Г. Кремень. Київ: Юрінком Інтер. 1040 с.

Завгородня, Т. К. (2020). Зарубіжний досвід моніторингу якості вищої освіти в дослідженнях вітчизняних науковців. Педагогічний альманах. Вип. 45. С. $165-171$.

Моніторинг якості освіти: світові досягнення та українські перспективи. (2004) / за заг. ред. О. І. Локшиної. Київ: К.І.С. 128 с.

Ішутіна, О. С. (2018). Проблема моніторингу якості вищої освіти в Україні. Science Review. № 5 (12). Vol. 1. C. $55-58$.

Ляшенко, О. I. (2007). Організаційно-методичні засади моніторингу якості освіти. Педагогіка і психологія. № 2. С. 34- 40 .

Майоров, А. Н. (2005). Мониторинг в образовании. Москва: Интеллект-Центр. 424 с.

Лукіна, Т. О. (2006). Моніторинг якості освіти: теорія і практика. Київ: Шкільний світ. 128 с.

\section{REFERENCES}

Orhanizatsiino-metodychne zabezpechennia monitorynhovykh doslidzhen yakosti zahalnoi serednoi osvity [Organizational and methodological support of monitoring studies on the quality of general secondary education]: monohrafiia. (2011) / za red. O. I. Liashenko. Kyiv: Pedahohichna dumka. $160 \mathrm{~s}$. [in Ukrainian].

Teoretyko-metodychni zasady pobudovy monitorynhovykh system otsiniuvannia yakosti zahalnoi serednoi osvity [Theoretical and methodological principles of building monitoring systems for assessing the quality of general secondary education]: monohrafiia. (2018) / za red. O. I. Liashenka, Yu. O. Zhuka. Kyiv: TOV «KONVI PRINT». 192 s. [in Ukrainian].

Natsionalna stratehiia rozvytku osvity v Ukraini na period do 2021 roku [National strategy for the development of education in Ukraine until 2021]: Ukaz Prezydenta Ukrainy vid 25.06.2013 r. № 344/2013. URL: https://zakon.rada.gov. ua/laws/show/344/2013\#Text (data zvernennia: 31.08.2021). [in Ukrainian].

Entsyklopediia osvity [Encyclopedia of education]. (2008) / Akad. ped. nauk Ukrainy; hol. red. V. H. Kremen. Kyiv: Yurinkom Inter. 1040 s. [in Ukrainian].

Zavhorodnia, T. K. (2020). Zarubizhnyi dosvid monitorynhu yakosti vyshchoi osvity v doslidzhenniakh vitchyznianykh naukovtsiv [Foreign experience of monitoring of the quality of higher education in the researches of domestic scientists]. Pedahohichnyi almanakh. Vyp. 45. S. 165-171. [in Ukrainian].

Monitorynh yakosti osvity: svitovi dosiahnennia ta ukrainski perspektyvy [Monitoring the education quality: global advances and Ukrainian perspectives]. (2004) / za zah. red. O. I. Lokshynoi. Kyiv: K.I.S. 128 s. [in Ukrainian].

Ishutina, O. Ye. (2018). Problema monitorynhu yakosti vyshchoi osvity v Ukraini [The problem of monitoring the quality of higher education in Ukraine]. Science Review. № 5 (12). Vol. 1. S. 55-58. [in Ukrainian].

Liashenko, O. I. (2007). Orhanizatsiino-metodychni zasady monitorynhu yakosti osvity [Organizational and methodological principles of education quality monitoring]. Pedahohika i psykholohiia. № 2. S. 34-40. [in Ukrainian].

Maiorov, A. N. (2005). Monytorynh v obrazovanyy [Monitoring in education]. Moskva: Yntellekt-Tsentr. 424 s. [in Russian].

Lukina, T. O. (2006). Monitorynh yakosti osvity: teoriia i praktyka [Monitoring the quality of education: theory and practice]. Kyiv: Shkilnyi svit. 128 s. [in Ukrainian].

Дата надходження до редакиії: 06.09.2021 p. 